\title{
SHORE GRYKES ALONG THE WESTERN ISTRIAN COAST
}

\section{OBALNI GRAJKI OB ZAHODNI ISTRSKI OBALI}

\author{
Stefano FURLANI ${ }^{1,3}$, Davide CHERSICLA ${ }^{2}$, Guido BRESSAN ${ }^{2}$, Sara BIOLCHI ${ }^{3,4} \&$ Franco CUCCHI $^{3}$
}

\begin{abstract}
UDC 551.4(497.5-16)

Stefano Furlani, Davide Chersicla, Guido Bressan, Sara Biolchi \& Franco Cucchi: Shore grykes along the western Istrian coast

We provided new data on topography, morphology and physi$\mathrm{cal} /$ chemical parameters $\left(\mathrm{pH}, \mathrm{T}, \mathrm{NO}^{2-}, \mathrm{Ca}^{2+}, \mathrm{PO}_{4}^{3-}, \mathrm{NaCl}\right.$ ) collected in several shore grykes along the Northwestern Istrian coast, between Savudrija and Zambratija. Six transects, each containing four to five pools, have been surveyed. Three morphological zones have been identified along the selected profiles. Morphological features of the shore grykes along the western Istrian coast are, in fact, closely related to the local tide. High-level pools are affected by karstic processes, and the surface is usually smooth. At their bottom, terrigenous deposits, mainly terra rossa, occur. Seaward, bioerosion prevails and at the bottom of the grykes, sand and rounded pebbles have been found. Chemical/physical parameters suggest that grykes located at lower altitudes are affected by seawater factors, while pools located at increasing altitudes are affected mainly by rainfall and consequentially freshwater or saltwater remaining from rainfalls or storm events. Shore gryke genesis is strongly controlled by geological weakness, along which they develop. Their origin is in fact due to local tectonics, while their development is related to the active vertical tectonic subsidence of the study area. Pools located at higher altitudes are mainly affected by solution karst processes, but due to the tectonic downdrop of the area, when the grykes come in contact with sea, they are gradually shaped by marine processes.
\end{abstract}

Keywords: coastal karst, Western Istria, shore grykes, tidepools, limestone.
Izvleček

UDK 551.4(497.5-16)

Stefano Furlani, Davide Chersicla, Guido Bressan, Sara Biolchi \& Franco Cucchi: Obalni grajki ob zahodni Istrski obali

$\mathrm{V}$ članku prestavimo nove topografske in morfološke izsledke ter fizikalno-kemične parametre izmerjene na izbranih obalnih grajkih severozahodne obale Istre med Savudrijo in Zambratijo. Raziskave smo omejili na šest profilov s štirimi do petimi plimskimi bazeni. $\mathrm{V}$ vseh profilih smo določili tri tipične morfološke cone, katerih značilnosti so tesno povezane z lokalnim plimovanjem. Višji bazeni so izpostavljeni zakrasevanju, zato so v njih oblike bolj gladke, v njihovem dnu pa prevladujejo sedimenti s kopnega, predvsem terra rossa. $\mathrm{V}$ smeri morja opazimo vse večji vpliv biokorozije. Ob vznožju grajkov najdemo peske in prodnike. Kemični parametri kažejo, da so nižje ležeči grajki izpostavljeni predvsem delovanju morske vode, medtem ko višje ležeče oblikuje predvsem deževnica. Razvoj obalnih grajkov je povezan $\mathrm{z}$ nezveznostmi, ki so posledica lokalnih tektonskih deformacij.

Ključne besede: obalni kras, zahodna Istra, obalni grajki, plimski bazeni, apnenec.

\footnotetext{
${ }^{1}$ Dipartimento di Geografia, Università degli Studi di Padova, Italy, e-mail: sfurlani73@gmail.com

${ }^{2}$ Dipartimento di Scienze della Vita, Università degli Studi di Trieste, Italy

${ }^{3}$ Dipartimento di Geoscienze, Università degli Studi di Trieste, Italy

${ }^{4}$ Dipartimento di Scienze della Terra, Università di Modena e Reggio Emilia, Italy

Received/Prejeto: 9.9.2010
} 


\section{INTRODUCTION}

The morphology of limestone coasts is determined by the presence of karst morphologies which have been inherited as a result of changes in the relative sea level, and consequently modified by marine processes (Trenhaile 1987). This mechanism is well-pronounced along recently subsiding areas, such as the Eastern Adriatic, where the development of coastal morphologies is conditioned by vertical tectonic movements.

In the intertidal zone along Western Istria, thanks to the gently sloping coast and the outcrop of limestone rocks, grykes, channels and, to a small extent, tidepools occur. Grykes are solutionally enlarged vertical or steeply inclined joints in the surface of a karstland, extending for up to a few meters into the limestone (Monroe 1970). A gryke is composed by several pools, sometimes coalescent or joined through siphons and filled by seawater during high tides or storms.

While tidepools on limestone coasts have been extensively studied (Ley 1979; Denny \& Gaines 2007), no relevant works can be found regarding shore grykes and channels. Although some considerations and methods regarding the study of tidepools can be exported to the study of shore grykes, the peculiarity and complexity of these morphologies suggest use of different shape indexes. Regarding the study of tidepools, Feldmann (1937), distinguished temporary pools and permanent pools depending on the time period in which there is water. These coastal features are, in fact, prominent structures that form in the intertidal zone where resistant bedrock is exposed (Griggs 2007). The type of rock exposed, the tidal range, the wave action, the erosion and the weathering processes acting on the rocks are significant in their genesis and development (De Waele et al. 2009).

The intertidal belt is affected by variable chemical/ physical conditions. It is subjected to seasonality, circadian differences and to rainfall, which can dilute the seawater, making it brackish. High biodiversity adds interest to the studied morphologies. Denny and Gaines (2007) recently provided a complete overview on tidepools. They are habitats of adaptable fauna and flora that, because of huge waves, strong currents and exposure to midday sun, fluctuations in sea level, water temperature, salinity and oxygen content, must be able to cope with a changing environment.

Few studies concern the morphology of limestone coasts along the Eastern Adriatic (D’Ambrosi 1948; Forti 1985; Perica et al. 2004; Fouache et al. 2000; Antonioli et al. 2007; Furlani et al. 2009), and no papers have dealt specifically with the fact that shore morphologies deepen here, despite the favourable conditions for their genesis and evolution. The present work started from a thesis in environmental sciences (Chersicla 2009), which provided data to study the Istrian limestone shore grykes.

The paper aims to provide new data on topography, morphological zonation and physical/chemical parameters ( $\mathrm{pH}, \mathrm{T}$, etc.) collected on several shore grykes along the northwestern Istrian coast, along six transects at Savudrija and Zambratija, and to discuss the evolution of the studied morphologies.

\section{STUDY AREA}

\section{GEOLOGICAL SETTING}

The study area is located between Savudrija and Zambratija (Northwestern Croatia, Fig. 1). In this sector of the Istrian coast, Early Cretaceous limestones, in particular Albian and Cenomanian in age, crop out. They correspond to a period of the evolution of the Adriatic Carbonate Platform (Vlahović et al. 2005) during which it was affected by periods of emergences due to the interaction of tectonics and eustatic changes. Lower Aptian deposits, in particular, represent an event connected with the partial drowning of the platform. During the transition between Aptian and Albian, the regional emersion of the platform occurred. Albian deposits are usually thin-bedded and are characterised by typical marginal features (desiccation cracks, ripple marks and dinosaur tracks). So during the Barremian, Aptian and Albian most of the platform was dominated by shallow subtidal environments rich in Foraminifera, with the gradual rise of rudists. During Late Cretaceous the platform attained its maturity and began to disintegrate (Velić et al. 2002). This process was accompanied by almost continuous synsedimentary tectonic activity, eustatic changes and extensive development of rudist communities. Lower Cenomanian deposits are characterised by facies affected by the synsedimentary tectonic defomation of the platform. After Middle Cenomanian a gradual re-unification occurred, with shallow-marine deposition (Vlahović et al. 2005).

The area is characterised by a gentle tectonic setting. The main structural framework is the Buje Anticline, 

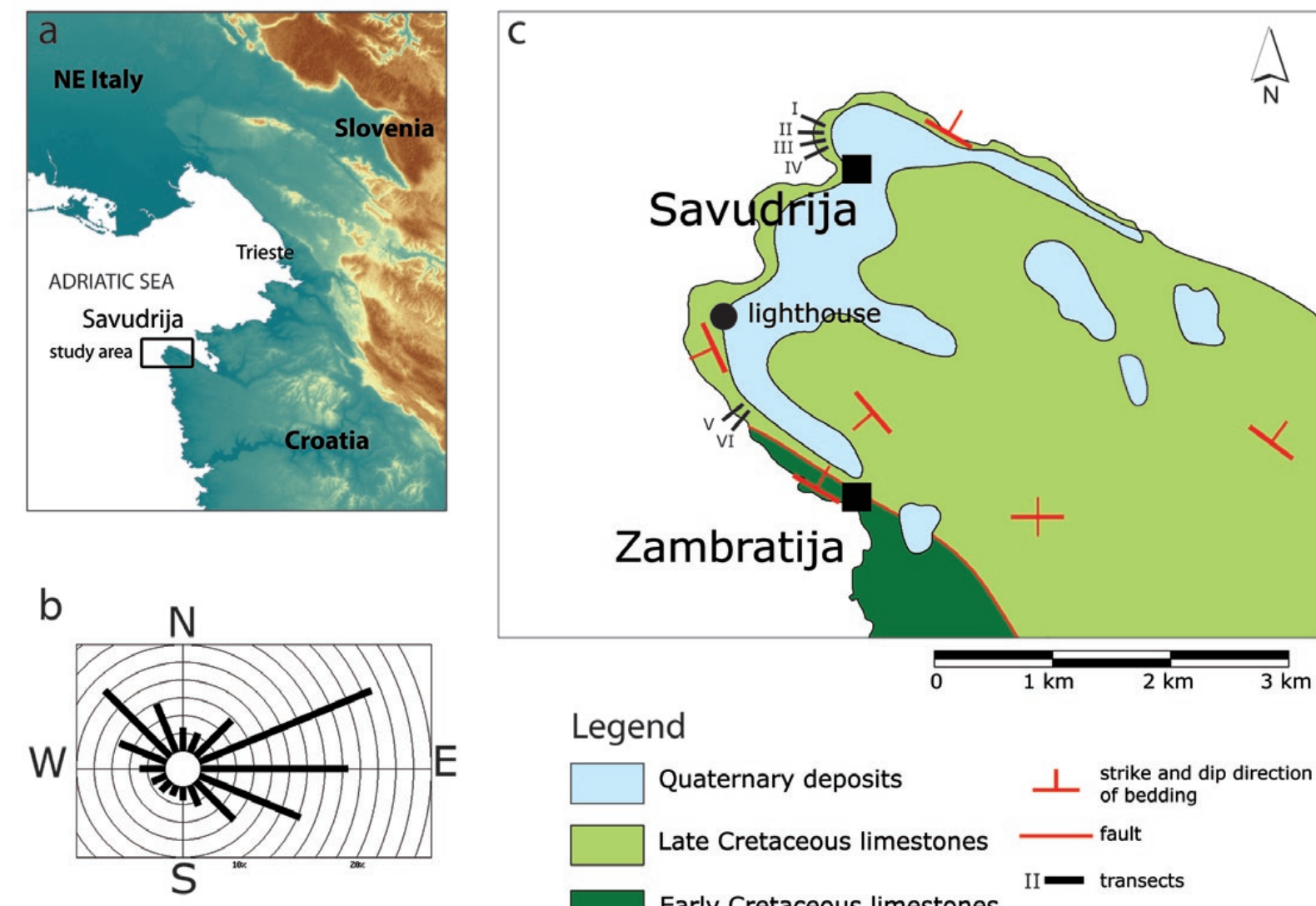

Legend

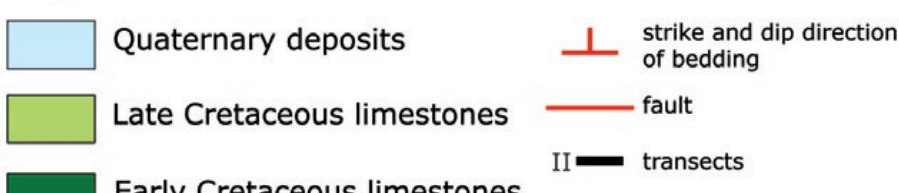

Early Cretaceous limestones

Fig. 1: Location of the transects in the study area. The base map (a) was created using SRTM data (Jarvis et al. 2008), while the geological map (c), that includes the location of the transects, is redrawn from Plenicar et al. (1973). b) The wind rose shows the dominant winds in the area (Stravisi 2003).

which stretches from Savudrija, across Buje, Oprtalj and Buzet, following the WNW-ESE direction. Considering the extension $(45 \mathrm{~km})$ of the structure, its genesis had to be followed by deformation of wider areas (Matičec 1994). Considering that the Dinaric structures differ in extension, orientation and strike from those parallel to the Buje Anticline, the last one should have been formed during a neotectonic phase, younger than Oligocene and Miocene, as a consequence of a recent global stress (NNE-SSW, Matičec 1994).

Seismotectonic activity is not relevant, even if the Northweastern Adriatic shores are acknowledged as being characterized by recent submersion. The underwater position of a number of intertidal morphologies or coastal anthropic structures (notches, platforms, Roman age remains, etc.) supports this idea (Fouache et al. 2000; Antonioli et al. 2004, 2007; Auriemma \& Karinja 2008; Furlani et al. 2010a, b; Faivre et al. 2010) and suggests that, in the Northwestern Istrian area, $2 \mathrm{ka}$ BP the sea level was $-1.6 \mathrm{~m}$ below msl, indicating vertical tectonic rates up to $-0.77 \mathrm{~mm} / \mathrm{yr}$.

\section{ENVIRONMENTAL SETTING}

Rainy winters and hot dry summers characterise the Mediterranean climate in the Istrian area. Mean annual rainfall measured in Trieste averages $1015 \mathrm{~mm} / \mathrm{yr}$ (Stravisi 2003). The minimum mean value was recorded in February, whereas the daily peak $(105 \mathrm{~mm})$ normally occurs in November. Storms are more frequent at the end of the summer and during autumn. In western Istria the mean rainfall is lower (Rovinj site, $766 \mathrm{~mm} / \mathrm{yr}$ ).

On average, there are 130 days/year when precipitation occurs. In a year there are approximately $31.5 \%$ rainy days, $64.4 \%$ sunny days, $3.0 \%$ snowy days and $1.1 \%$ days with hail (Tommasini 1979). The average annual temperature along the studied coast is approximately $16^{\circ} \mathrm{C}$. The hottest month is August $\left(24^{\circ} \mathrm{C}\right)$, whereas the coldest one is January, having temperatures lower than $6^{\circ} \mathrm{C}$.

The area is characterised by a prevalence of winds blowing from the first quadrant, mainly from the ENE (Bora) (Carrera et al. 1995). South-easterly winds (Scirocco or Jugo) are important because of the wide fetch (over $800 \mathrm{~km}$ ). Tides are semi-diurnal, with mean 
spring-tide values of $0.86 \mathrm{~m}$ in Trieste, and mean neaptide values of $0.22 \mathrm{~m}$ (Dorigo 1965; Polli 1970). The concomitance of spring tides, seiches, south-easterly winds and low atmospheric pressure can cause a sea-level rise of $1.60 \mathrm{~m}$. Along the northern Istrian coast, tides are $80 \%$ of those at Trieste. The winds of the Southwest and the Northwest quadrant raise it, thus leading to "highwater" phenomena. Mean significant wave height during the year is lower than $0.5 \mathrm{~m}$ (Dal Cin \& Simeoni 1994), while the highest offshore wave height, both for Bora and Scirocco storms, is about $5 \mathrm{~m}$ (Cavaleri et al. 1996). The highest mean hourly speed for southeast wind in the period $1958-1987$ was $27.3 \mathrm{~m} / \mathrm{s}$.

An estimate of wave energy for the Northern Adriatic area in the form of H2T2 ( $\mathrm{H}$ and T corresponding to the significant wave height and period) was studied using the complete series of 2000-2003 three-hourly measurements available from the RON-APAT (Fontolan et al. 2007) wave gauge located offshore Ancona (latitude 43.3704600 , longitude 13.3001300). The annual value is $15.61 \mathrm{~m}^{2} \mathrm{~s}^{2}$.

Mean sea temperatures range between 9 and $11^{\circ} \mathrm{C}$, with peaks in August $\left(24^{\circ} \mathrm{C}\right)$. Seawater salinity displays higher values in winter than during summer and ranges between 34 and 39 psu (Miramare oceanographic buoy). Frost is rare and affects mainly the sheltered areas of the bays.

Biogeochemical parameters, on a seasonal-climatological basis, in the Northern Adriatic Sea have been studied by Zavatarelli et al. (1998). Surface $\mathrm{NO}^{2-}$ distribution during winter decreases in the WE direction, so it is moved by barocline circulation. Moreover it is lower during spring-summer, probably because it is used by plants for metabolic processes. $\mathrm{PO}_{4}^{3-}$ is usually very low in the northern Adriatic (Degobbis 1990; Krom et al. 1991; Giani et al. 2003), and it decreases in the eastward direction, so the northern Adriatic Sea can be considered phospho-limited. $\mathrm{O}_{2}$ concentrations are higher than $8 \mathrm{mg} / \mathrm{l}$, sometimes higher than $14 \mathrm{mg} / \mathrm{l}$. Maximum values have been observed during spring because of low temperatures and algal activity, while minimum values have been observed during summer, mainly because of increasing temperatures and salinity. Seawater in the Gulf of Trieste is generally higher than $8 \mathrm{mg} / \mathrm{l} \mathrm{O}_{2}$ (www.arpa.fvg.it).

\section{MATERIALS AND METHODS}

\section{TOPOGRAPHICAL MEASUREMENTS}

Six perpendicular shore transects (Figs. $2 \& 3$ ) have been measured using the method suggested by Hunt (2007) and Antonioli et al. (2007) to measure coastal morphologies and Roman remains. Figures 2 and 3 represent schematic transects; in fact only the threshold and the bottom of the gryke have been reported, considering the particular importance of these parameters. The bottom is, in fact, generally flat while the threshold is the "gate" through which the water flows into the gryke.

Altitudinal measurements and distances have been collected using, respectively, an optical (Salmoiraghi Ertel automatic level), or a laser level and a measuring tape. We measured (Table 1) the elevation (m msl) of the bottom of the gryke, the height of the gryke (m), the distance from the shore $(\mathrm{m})$, the length $(L, \mathrm{~m})$, the width $(l, \mathrm{~m})$ and the eccentricity $(L / l)$, obtained as the ratio between length and width. We use the terms used by Lewis (1964), that is: high-level pools (or grykes) to indicate the pools located at higher altitudes above sea level (supratidal zone), and mid-level (intertidal) or lowlevel (subtidal) to the others.

Altitudinal measurement consists of: 1) measurement of the depth of the marker with respect to the lo- cal sea level at the time of surveying. Values reported in Table 1 represent the mean value of multiple measures; 2) correction of surveyed measures with respect to the nearest tide gauge data collected at the time of surveying. Error bars for the elevation and age values of the sea level markers have been provided in order to consider the inaccuracy of measures.

Elevation measurements were collected via optical (Salmoiraghi Ertel automatic level) or mechanical instruments (invar rod) or with a laser level. The surveying was performed during periods of low wave energy in order to minimize the errors. Measurements have been reduced to the mean sea level applying tidal corrections at the surveyed sites, using the data of the Trieste tide gauge. In fact, tide amplitude is particularly significant in the northern Adriatic Sea, as it can be up to $\sim 2 \mathrm{~m}$. Elevation measurements are given (Stravisi \& Purga 2005) with respect to the Italian reference plane network of the Istituto Geografico Militare (Genova Mean Sea Level 1942; Gamboni 1965).

Limestone samples have been collected using a geological hammer. The rock identification has been carried out through thin sections in the Department of Geosci- 


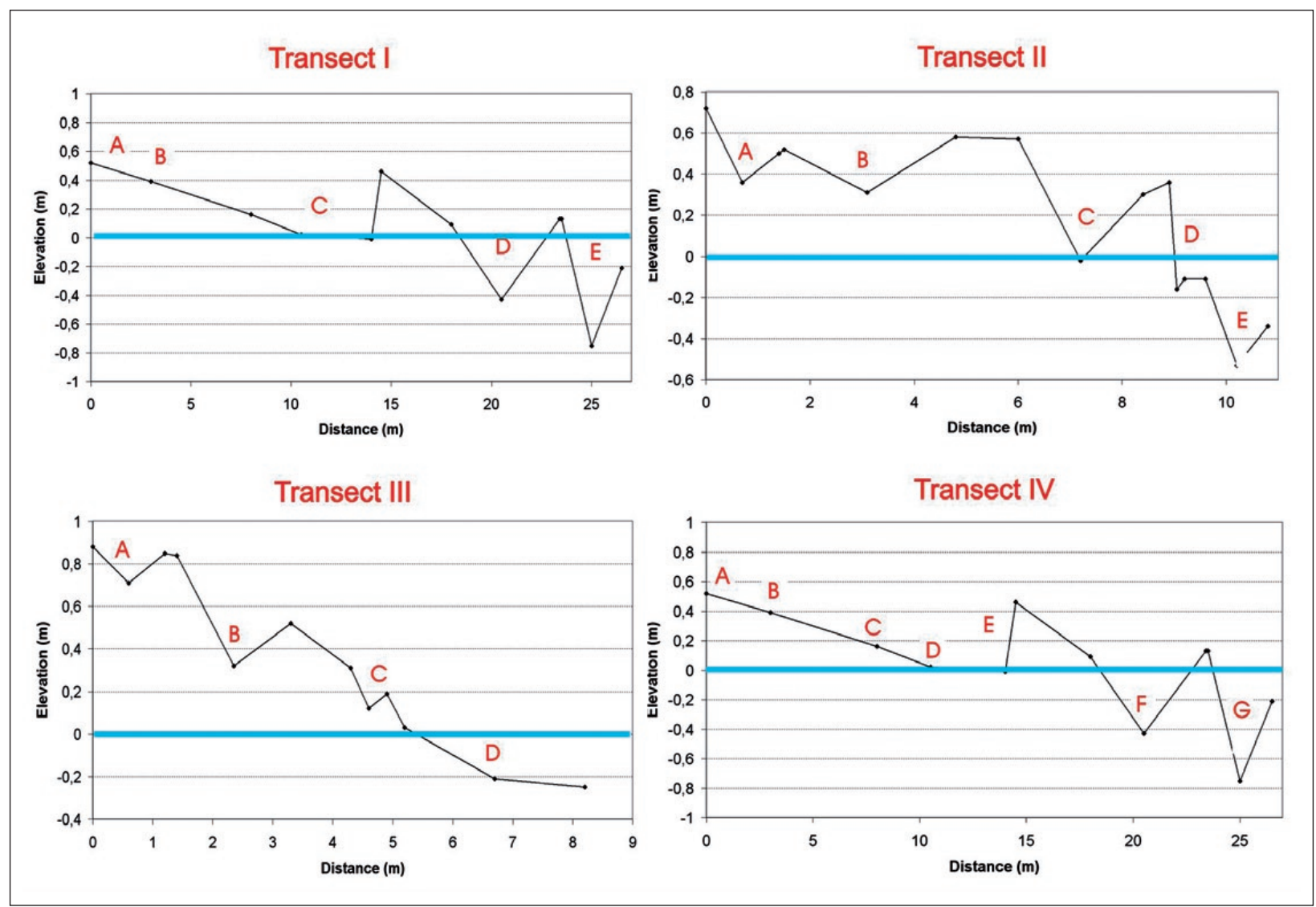

Fig. 2: Topographical transects at Savudrija. The thick line indicates the mean sea level. Capital letters indicate the pools on the surveyed grykes. $A$ is the gryke at the highest elevation, while the following letters indicate as lower grykes.
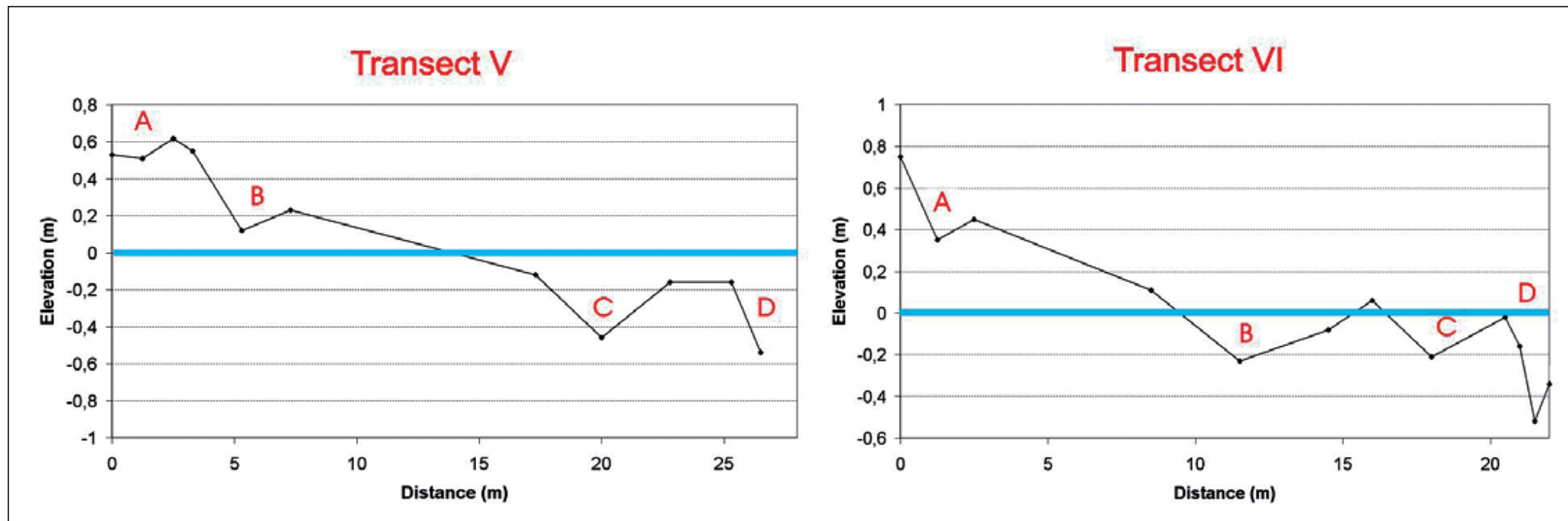

Fig. 3: Topographical transects at Zambratija. The thick line indicates the mean sea level. Capital letters indicate the pools on the surveyed grykes. A is the gryke at the highest elevation, while the following letters indicate as lower grykes.

ences in Trieste. The geographic locations have been obtained using a GPS Garmin $12^{\circ}$.

The multivariate analysis was carried out using SPSS software, by means of topographical variables (bottom depth elevation and distance from the shore). The Euclidean quadratic distance has been used as index, and the Ward's criterion was used for the cluster-analysis.

\section{CHEMICAL/PHYSICAL MEASUREMENTS}

Salinity (psu). $\mathrm{NO}^{2-}, \mathrm{Ca}^{2+}, \mathrm{PO}_{4}^{3-}, \mathrm{NaCl}$ and $\mathrm{pH}$ have been collected using field instruments during winter, spring and summer, 2008 (Tab. 2-4). Chemical/physical data have been reported in Tab. 2-4 depending on the season. The day and hour of measurement are reported for every 
transect. "No data" indicates that it was not possible to measure because the pool was empty.

The Tetratest ${ }^{\oplus}$ kit, a fast and effective qualitative method, was used to measure dissolved $\mathrm{O}_{2}$ and nutrients $\left(\mathrm{NO}^{2-}, \mathrm{NO}^{3-}, \mathrm{Ca}^{2+}, \mathrm{PO}_{4}^{3-}\right)$; salinity was measured using the Hand Refractometer S/mill-E ATAGO ${ }^{\circ}$ while the temperature, $\mathrm{pH}$ and salinity were collected using the multiparametric Waterproof Handheld pH/Cond Meter XS PC650.

\section{SELECTION OF TRANSECTS}

Six transects, marked by roman numbers (I to VI), perpendicular to the shore and located between the lower tidal zone and the supratidal zone have been studied. They are composed of a number of pools, grykes, breaches and channels named with capital letters ( $\mathrm{A}$ is the morphology located most inland, and the letters progress toward the shore, Figs. $2 \& 3$ ).
Four transects are located near the Lighthouse of Savudrija (Figs. 1 \& 2), while two transects are located near Zambratija (Figs. 1 \& 3).

They have been chosen with respect to the following criteria:

- the proximity between the transects;

- all the transects are roughly E-W oriented, so wind and wave action is similar;

- every transect has different slope degrees and different elevations above mean sea level;

- the dimension and shape of the studied morphologies are different in every transect;

- in Savudrija the transects are lightly affected by anthropic influence due to the presence of a camping area;

- in Zambratija the study area is not affected by human presence.

\section{RESULTS}

Collected data are reported in Tab. 1-5. In Tab. 1 topographical and morphological data are reported; in Tab. 2, 3 and 4 physical/chemical parameters collected respectively during winter (Tab. 2), spring (Tab. 3) and summer (Tab. 4), while in Tab. 5 the results of the cluster analysis are reported.

\section{SITE DESCRIPTION}

The topographical and morphological description of the pools is reported in Tab. 1. The surveyed pool, the elevation of the bottom ( $\mathrm{m} \mathrm{msl}$ ), the height of the pool (m), the minimum distance from the shore (m), the eccentricity (ratio between length and width), the nature of deposits on the bottom of the pool and the nature of slope weathering have been considered.

The location of the transects at Savudrija (Fig. 5) and the number of morphologies surveyed is reported following:

- transect I $\left(45^{\circ} 29^{\prime} 23^{\prime \prime} \mathrm{N} ; 13^{\circ} 29^{\prime} 26^{\prime \prime} \mathrm{E}\right)$ : it is located just below the Savudrija Lighthouse. It consists of five pools (Fig. 2);

- transect II $\left(45^{\circ} 29^{\prime} 22^{\prime \prime} \mathrm{N} ; 1^{\circ} 29^{\prime} 26^{\prime \prime} \mathrm{E}\right)$ : it is located a few meters south of the first transect. It consists of four pools (Fig. 2);

- transect III $\left(45^{\circ} 29^{\prime} 20^{\prime \prime} \mathrm{N} ; 13^{\circ} 29^{\prime} 27^{\prime \prime} \mathrm{E}\right)$ : it is located $70 \mathrm{~m}$ south from transect II. It consists of four coalescent pools (Fig. 2);

- transect IV $\left(45^{\circ} 29^{\prime} 18^{\prime \prime} \mathrm{N} ; 1^{\circ} 29^{\prime} 27^{\prime \prime} \mathrm{E}\right)$ : it is located a few meters south of transect III, near an artificial ce- mented pool. It can be considered a meandered channel; letters indicate significant points, mainly in correspondence to the curves of the meander (Fig. 2);

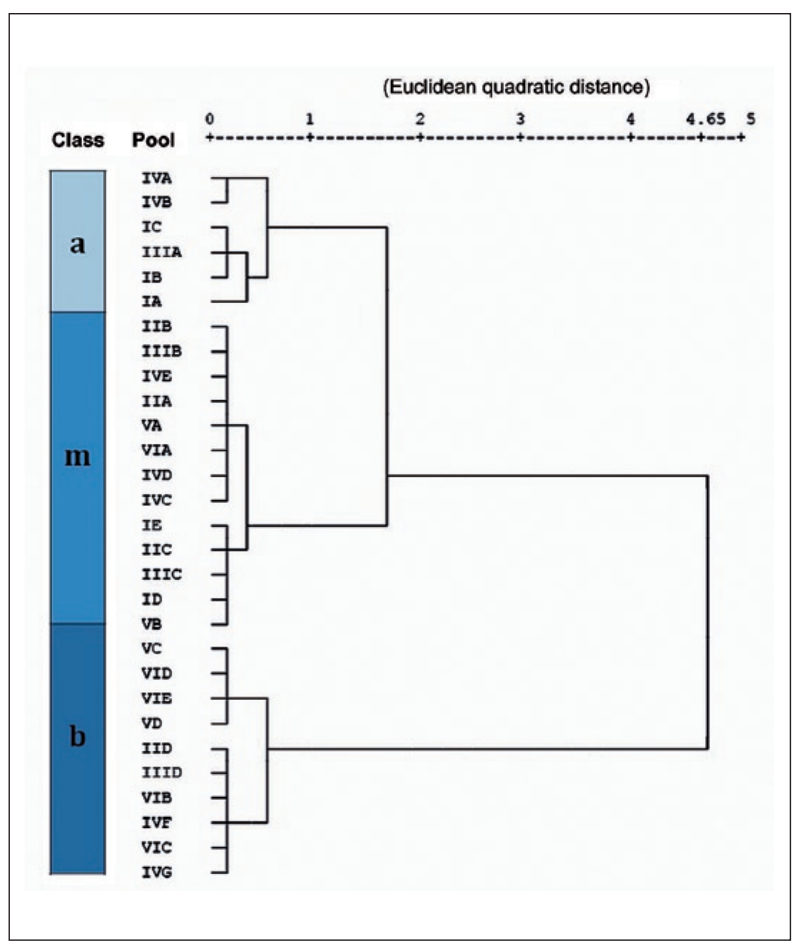

Fig 4: Dendrogram of the hierarchical classification of the shore grykes considering the topographical data. 
Tab. 1: Topographical and geomorphological data of the surveyed morphologies. The table reports: the name of the transect and number of the surveyed pool (pool is generically intended as erosional feature), the elevation of the bottom of the pool ( $m$ msl), the maximum height of the pool ( $\mathrm{m} \mathrm{msl}$ ), the mean distance of the pool from the shore $(\mathrm{m})$; the eccentricity, that is the ratio between the length and the width, the nature of the deposits accumulated at the bottom of the pool and the nature of slope weathering.

\begin{tabular}{|c|c|c|c|c|c|c|}
\hline \multirow[b]{2}{*}{ Pool } & \multicolumn{3}{|c|}{ Topography } & \multicolumn{3}{|c|}{ Morphology } \\
\hline & $\begin{array}{c}\text { Bottom } \\
\text { elevation }(m)\end{array}$ & $\begin{array}{l}\text { Total height } \\
\text { (m) }\end{array}$ & $\begin{array}{c}\text { Distance from } \\
\text { the shore } \\
(m)\end{array}$ & $\begin{array}{c}\text { Eccentricity } \\
(L / I)\end{array}$ & Deposits on the bottom & Slope weathering \\
\hline $\mathrm{IA}$ & 1.35 & 1.47 & 10.5 & 2 & terrigenous & smooth \\
\hline IB & 0.8 & 0.98 & 8.5 & 4.25 & terrigenous & smooth \\
\hline IC & 0.51 & 0.67 & 1 & n.p. & man-made & karstic solution \\
\hline ID & -0.18 & 0.07 & -2 & 0.36 & rounded clasts & biocorroded \\
\hline $\mathrm{IE}$ & -0.31 & 0.21 & -4.8 & 0.22 & rounded clasts & biocorroded \\
\hline II A & 0.36 & 0.55 & 7.6 & 2 & terrigenous & karstic solution \\
\hline II B & 0.31 & 0.63 & 4.2 & 4.12 & angular clasts & karstic solution \\
\hline$\| \mathrm{C}$ & -0.02 & 0.35 & 0.6 & 1.85 & angular clasts & biocorroded \\
\hline II D & -0.16 & -0.06 & -0.2 & 0.18 & rounded clasts & biocorroded \\
\hline IIE & -0.53 & -0.29 & -1.8 & 0.48 & rounded clasts & biocorroded \\
\hline III A & 0.71 & 1.00 & 4.3 & 1.71 & terrigenous & smooth \\
\hline III B & 0.32 & 0.67 & 2.2 & 1.36 & terrigenous & karstic solution \\
\hline III C & 0.12 & 0.34 & 0.3 & 3 & small clasts & biocorroded \\
\hline III D & -0.21 & -0.10 & -1.5 & 1.67 & rounded clasts & biocorroded \\
\hline IV A & 0.52 & 0.72 & 18.5 & n.p. & terrigenous & karstic solution \\
\hline IV B & 0.39 & 0.59 & 15.5 & n.p. & terrigenous & karstic solution \\
\hline IVC & 0.16 & 0.36 & 10.5 & n.p. & small clasts & karstic solution \\
\hline IV D & 0.02 & 0.22 & 8.5 & n.p. & small clasts & karstic solution \\
\hline IVE & -0.01 & 0.66 & 4 & n.p. & small clasts & karstic solution \\
\hline IV F & -0.43 & 0.33 & -5 & 1.57 & rounded clasts & biocorroded \\
\hline IV G & -0.75 & -0.01 & -6.5 & 2.5 & rounded clasts & biocorroded \\
\hline V A & 0.51 & 0.57 & 11.5 & 5 & terrigenous & karstic solution \\
\hline V B & 0.12 & 0.18 & 6.7 & 2.67 & terrigenous & karstic solution \\
\hline VC & -0.46 & -0.21 & -8.8 & 5.5 & sand and clasts & biocorroded \\
\hline VD & -0.54 & -0.59 & -12.5 & 6.25 & sand and clasts & biocorroded \\
\hline VI A & 0.35 & 0.45 & 14 & 2.08 & terrigenous & karstic solution \\
\hline VI B & -0.23 & -0.08 & 2 & 2 & sand and clasts & biocorroded \\
\hline VIC & -0.12 & -0.02 & -4 & 5 & rounded clasts & biocorroded \\
\hline VID & -0.52 & -0.34 & -5 & 2 & rounded clasts & biocorroded \\
\hline VIE & n.p. & -0.52 & -5.5 & n.p. & rounded clasts & biocorroded \\
\hline
\end{tabular}

The location of the transects at Zambratija (Fig. 6) and the number of morphologies surveyed is reported following:

- transect V $\left(45^{\circ} 29^{\prime} 18^{\prime \prime} \mathrm{N} ; 13^{\circ} 29^{\prime} 27^{\prime \prime} \mathrm{E}\right)$ : it is located $1500 \mathrm{~m}$ south of transect IV. It consists of four pools (Fig. 3);

- transect VI ( $\left.45^{\circ} 29^{\prime} 18^{\prime \prime} \mathrm{N} ; 3^{\circ} 29^{\prime} 27^{\prime \prime} \mathrm{E}\right)$ : it is located a few meters south of transect V. It consists of five pools (Fig. 3).

\section{TOPOGRAPHICAL RESULTS}

Topographical results have been reported in Tab. 1. The elevation ( $\mathrm{m} \mathrm{msl}$ ) of the bottom of the studied grykes ranges between $-0.75 \mathrm{~m}$ (transect IV) and $1.35 \mathrm{~m}$ (transect I).
The height of the threshold of the grykes ranges between $1.47 \mathrm{~m}$ (transect I) and $-0.59 \mathrm{~m}$ (transect V). The maximum distance from the shore is $18.5 \mathrm{~m}$ (transect IV). The eccentricity ranges between 6.25 and 0.18 . In many cases it was impossible to calculate eccentricity because of the complex shape of the gryke. Deposits on the bottom of the grykes are mainly terrigenous (terra rossa) in the high-level grykes (Fig. 7), while grykes at lower altitudes are filled with sand or rounded pebbles. The bottom of one pool (IC) is cemented. Observations on the rock surface suggest that biocorroded surfaces are located at lower altitudes, while at higher altitudes karstic solution prevails. Some surfaces at higher altitudes seem to be smoothed by running waters. 

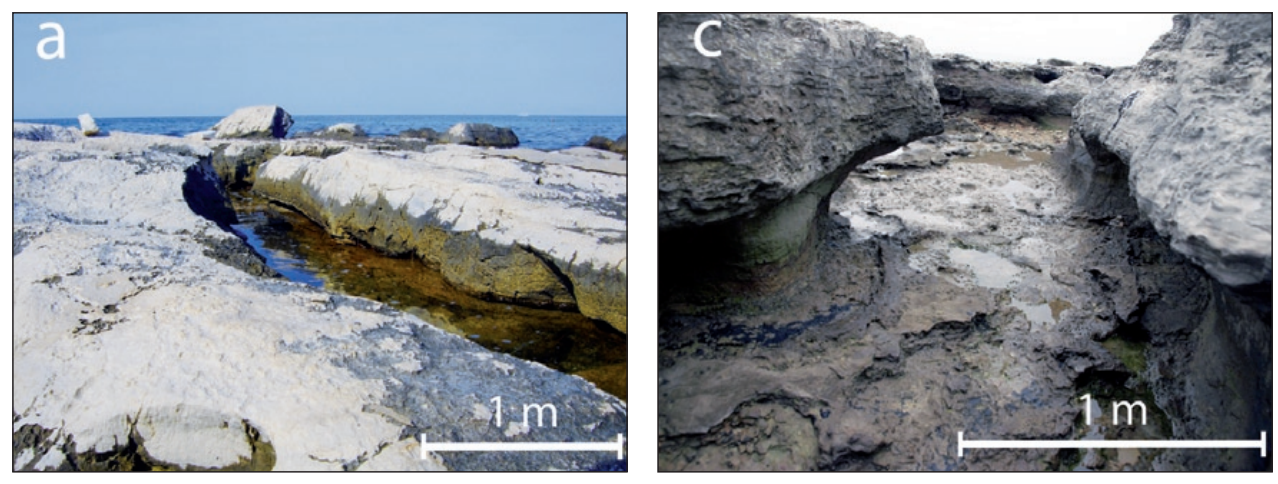

Fig. 5: Shore grykes at Savudrija: $a, b)$ view of pools at Savudrija collected respectively during low and high tide; c) notch morphologies bordering pools of the transect $I V$; d) pools at higher altitudes of the transect I (Photos: S. Furlani).
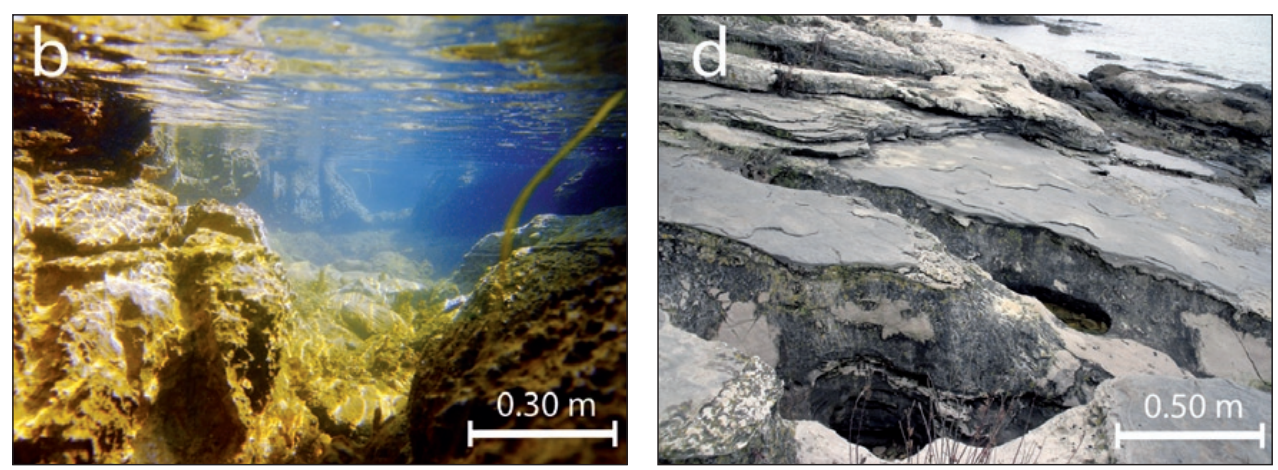
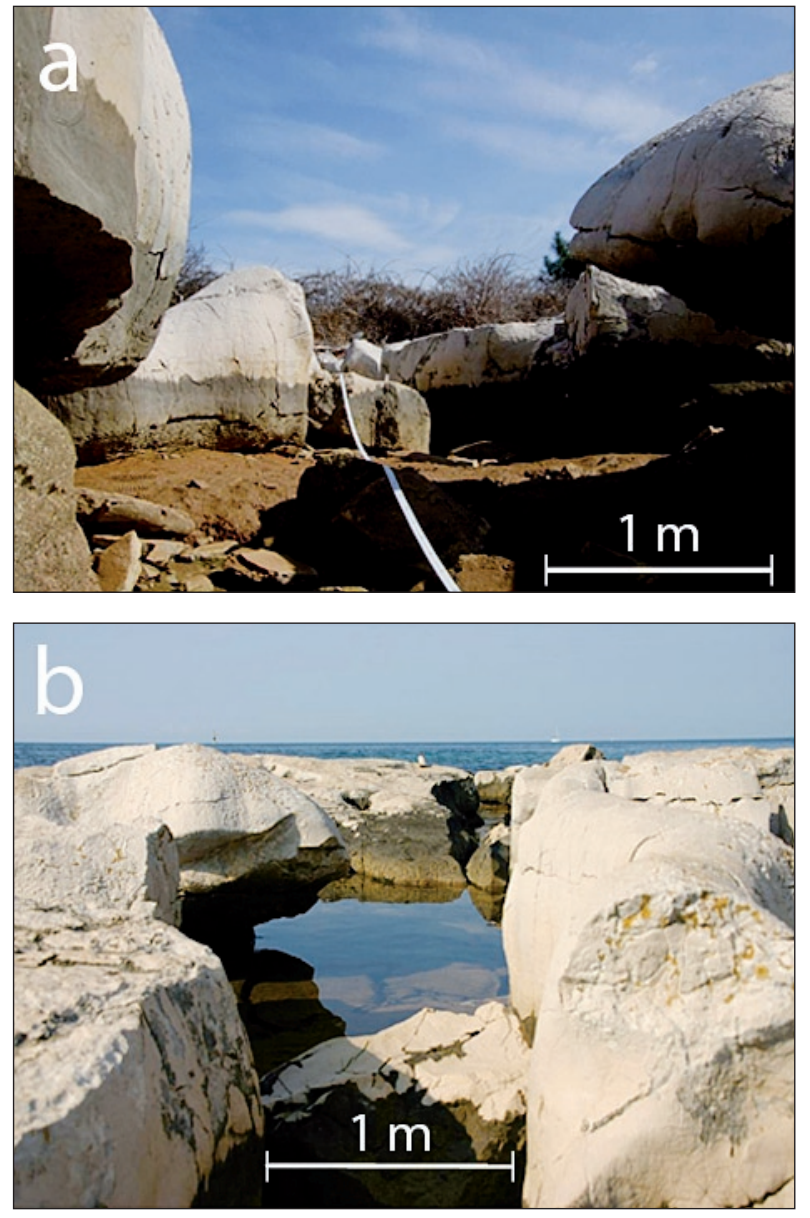

The multivariate analysis (Tab. 5, Fig. 4) highlights a strong positive correlation between the clusters; the considered topographical parameters decrease proportionally between an element of cluster A and an element of cluster M or B (Tab. 5). Pools belonging to cluster A can be roughly identified with the pools of the spray zone (supralittoral), while pools belonging to cluster $\mathrm{M}$ and $\mathrm{B}$ are the grykes located in the intertidal or subtidal zone.

\section{LITHOLOGICAL DESCRIPTION}

Savudrija transects (Fig. 2): four limestone beds, Albian in age, occur. The bedding strike direction is W $335 \mathrm{~N}$ with respective dip angle of 10 . From the bottom to the top, beds are defined as follows:

- $60 \mathrm{~cm}$ laminated dark grey limestone with sporadic subrounded millimetric or centimetric white plasticlasts characterised by wackestone texture;

- $20 \mathrm{~cm}$ grey limestone with several millimetric or centimetric white plasticlasts with wackestone texture;

- $60 \mathrm{~cm}$ fossiliferous light grey limestone with grainstone texture, characterised by several Rudist fragments;

Fig. 6: Shore grykes at Zambratija: a) the fractures have been shaped mainly by mechanical abrasion; b) view of the transect VI. At the base of the pools, terra rossa occurs (Photos: S. Furlani). 
Tab. 2: Physical/chemical parameters collected during winter.

\begin{tabular}{|c|c|c|c|c|c|c|c|c|c|}
\hline pool & $\begin{array}{c}\text { Temp. } \\
\left({ }^{\circ} \mathrm{C}\right)\end{array}$ & $\begin{array}{c}\mathrm{O}_{2} \\
(\mathrm{mg} / \mathrm{l})\end{array}$ & $\begin{array}{c}\mathrm{NO}_{2} \\
(\mathrm{mg} / \mathrm{l})\end{array}$ & $\begin{array}{c}\mathrm{NO}_{3} \\
(\mathrm{mg} / \mathrm{l})\end{array}$ & $\begin{array}{c}C a^{2} \\
(m g / l)\end{array}$ & $\begin{array}{c}\mathrm{PO}_{4}^{3-} \\
(\mathrm{mg} / \mathrm{l})\end{array}$ & $p H$ & $\begin{array}{l}\text { Salinity } \\
\text { (psu) }\end{array}$ & date and hour \\
\hline$I A$ & 9.0 & 14 & $<0.3$ & 10 & 120 & 0 & 9.68 & 0 & \multirow{5}{*}{$\begin{array}{l}8 \\
0 \\
\frac{0}{\pi} \\
\frac{0}{0}\end{array}$} \\
\hline$I B$ & 8.9 & 14 & $<0.3$ & 12.5 & 120 & 0 & 9.37 & 5 & \\
\hline$I C$ & 9.5 & 14 & $<0.3$ & 0 & 580 & 0 & 8.91 & 50 & \\
\hline$I D$ & 9.8 & 14 & $<0.3$ & 0 & 580 & 0 & 8.12 & 38 & \\
\hline$I E$ & 10.5 & 14 & $<0.3$ & 0 & 580 & 0 & 8.24 & 38 & \\
\hline IIA & 9.0 & 11 & $<0.3$ & 12.5 & 625 & 0 & 8.49 & 25 & \multirow{4}{*}{ 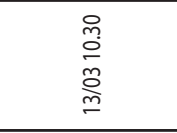 } \\
\hline$I I B$ & 8.7 & 11 & $<0.3$ & 12.5 & 650 & 0 & 8.35 & 29 & \\
\hline IIC & 9.5 & 11 & $<0.3$ & 12.5 & 725 & 0 & 8.22 & 37 & \\
\hline$I I D$ & 9.6 & 14 & $<0.3$ & 12.5 & 500 & 0 & 8.28 & 36 & \\
\hline III A & 8.5 & 8 & $<0.3$ & 12.5 & 650 & 0 & 7.60 & 11 & \multirow{4}{*}{$\begin{array}{l}\stackrel{8}{0} \\
\stackrel{1}{m} \\
\stackrel{m}{m}\end{array}$} \\
\hline III B & 9.3 & 11 & $<0.3$ & 12.5 & 675 & 0 & 8.59 & 25 & \\
\hline III C & 9.7 & 14 & $<0.3$ & 12.5 & 700 & 0 & 8.29 & 36 & \\
\hline$I I I D$ & 9.7 & 14 & $<0.3$ & 12.5 & 700 & 0 & 8.35 & 35 & \\
\hline$I V A$ & 6.5 & 8 & $<0.3$ & 12.5 & 900 & 0 & 8.56 & 46 & \multirow{6}{*}{$\begin{array}{l}\frac{8}{0} \\
\frac{m}{m} \\
\stackrel{m}{m}\end{array}$} \\
\hline$I V C$ & 2.9 & 11 & $<0.3$ & 12.5 & 675 & 0 & 8.70 & 46 & \\
\hline$I V D$ & 5.0 & 11 & $<0.3$ & 12.5 & 675 & 0 & no data & 43 & \\
\hline$I V E$ & 6.1 & 11 & $<0.3$ & 12.5 & 675 & 0 & 7.92 & 44 & \\
\hline$I V F$ & 6.1 & 14 & $<0.3$ & 12.5 & 500 & 0 & 8.35 & 41 & \\
\hline$I V G$ & 8.7 & 14 & $<0.3$ & 12.5 & 500 & 0 & 8.36 & 35 & \\
\hline$V A$ & 8.0 & 11 & 0.3 & 0 & 440 & 0 & 8.18 & 38 & \multirow{4}{*}{ 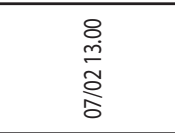 } \\
\hline$V B$ & 13.3 & 11 & $<0.3$ & 0 & 540 & 0 & 8.62 & 39 & \\
\hline$V C$ & 9.2 & 11 & $<0.3$ & 12.5 & 540 & 0 & 8.15 & 38 & \\
\hline$V D$ & 10.2 & 11 & $<0.3$ & 12.5 & 540 & 0 & 8.17 & 37 & \\
\hline$V I A$ & 12.8 & 8 & $<0.3$ & 0 & 480 & 0 & 8.22 & 27 & \multirow{5}{*}{ 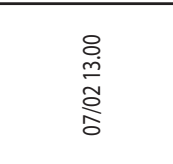 } \\
\hline$V I B$ & 10.1 & 11 & $<0.3$ & 12.5 & 580 & 0 & 8.31 & 36 & \\
\hline VIC & 9.1 & 11 & $<0.3$ & 12.5 & 580 & 0 & 8.16 & 37 & \\
\hline$V I D$ & 9.4 & 11 & $<0.3$ & 12.5 & 580 & 0 & 8.16 & 40 & \\
\hline VIE & 10.1 & 11 & $<0.3$ & 12.5 & 580 & 0 & 8.21 & 40 & \\
\hline
\end{tabular}

Tab. 3: Physical/chemical parameters collected during spring.

\begin{tabular}{|c|c|c|c|c|c|c|c|c|c|}
\hline pool & $\begin{array}{c}\text { Temp. } \\
\left({ }^{\circ} \mathrm{C}\right)\end{array}$ & $\begin{array}{c}\mathrm{O}_{2} \\
(\mathrm{mg} / \mathrm{l})\end{array}$ & $\mathrm{NO}_{2}(\mathrm{mg} / \mathrm{l})$ & $\begin{array}{c}\mathrm{NO}_{3} \\
(\mathrm{mg} / \mathrm{l})\end{array}$ & $\begin{array}{c}C a^{2} \\
(m g / l)\end{array}$ & $\begin{array}{c}\mathrm{PO}_{4}^{3-} \\
(\mathrm{mg} / \mathrm{l})\end{array}$ & $p H$ & $\begin{array}{c}\text { Salinity } \\
\text { (psu) }\end{array}$ & date and hour \\
\hline$I A$ & no data & no data & no data & no data & no data & no data & no data & no data & \multirow{5}{*}{$\begin{array}{l}\stackrel{ }{N} \\
\frac{8}{\delta} \\
\frac{\delta}{\delta}\end{array}$} \\
\hline$I B$ & no data & no data & no data & no data & no data & no data & no data & no data & \\
\hline$I C$ & 25.7 & 11 & $<0.3$ & 0 & 625 & 0 & 8.60 & 36 & \\
\hline$I D$ & 23.1 & 14 & $<0.3$ & 0 & 550 & 0 & 8.42 & 39 & \\
\hline$I E$ & 22.0 & 14 & $<0.3$ & 0 & 500 & 0 & 8.27 & 39 & \\
\hline$\| A$ & 28.5 & 8 & $<0.3$ & 12.5 & 500 & 0 & 8.33 & 20 & \multirow{4}{*}{ 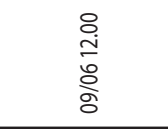 } \\
\hline II B & 28.1 & 11 & $<0.3$ & 12.5 & 500 & 0 & 8.46 & 26 & \\
\hline IIC & 24.7 & 14 & $<0.3$ & 0 & 500 & 0 & 8.18 & 35 & \\
\hline$I I D$ & 23.9 & 14 & $<0.3$ & 0 & 500 & 0 & 8.27 & 36 & \\
\hline III A & 19.8 & 8 & $<0.3$ & 0 & 650 & 0 & 8.07 & 13 & \multirow{4}{*}{$\begin{array}{l}\frac{m}{E} \\
\frac{g}{\varnothing} \\
\frac{8}{0}\end{array}$} \\
\hline III B & 26.7 & 14 & $<0.3$ & 0 & 675 & 0 & 8.94 & 24 & \\
\hline IIIC & 24.0 & 14 & $<0.3$ & 0 & 550 & 0 & 8.60 & 40 & \\
\hline IIID & 25.4 & 14 & $<0.3$ & 0 & 500 & 0 & 8.19 & 34 & \\
\hline$I V A$ & 27.0 & 8 & 0.8 & 12.5 & 700 & 0 & 9.07 & 2 & \multirow{6}{*}{ 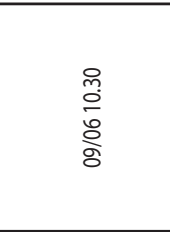 } \\
\hline$I V C$ & 28.5 & 11 & 0.3 & 12.5 & 600 & 0 & 8.66 & 28 & \\
\hline$I V D$ & 26.3 & 11 & $<0.3$ & 12.5 & 600 & 0 & 8.66 & 30 & \\
\hline$I V E$ & 26.3 & 14 & $<0.3$ & 0 & 520 & 0 & 8.66 & 30 & \\
\hline$I V F$ & 25.3 & 14 & $<0.3$ & 0 & 550 & 0 & 8.12 & 36 & \\
\hline$I V G$ & 22.0 & 14 & $<0.3$ & 0 & 550 & 0 & 8.27 & 38 & \\
\hline$V A$ & no data & no data & no data & no data & no data & no data & no data & no data & \multirow{4}{*}{$\begin{array}{l}\text { 을 } \\
\frac{m}{6} \\
\frac{8}{8}\end{array}$} \\
\hline$V B$ & 23.2 & 14 & $<0.3$ & 0 & 480 & 0 & 8.31 & 38 & \\
\hline$V C$ & 21.0 & 14 & $<0.3$ & 0 & 480 & 0 & 8.30 & 40 & \\
\hline$V D$ & 21.0 & 14 & $<0.3$ & 0 & 580 & 0 & 8.30 & 40 & \\
\hline$V I A$ & 23.5 & 11 & $<0.3$ & 0 & 440 & 0 & 8.29 & 39 & \multirow{5}{*}{$\begin{array}{l}\frac{8}{1} \\
\frac{1}{8} \\
\frac{8}{8}\end{array}$} \\
\hline$V I B$ & 23.7 & 8 & $<0.3$ & 12.5 & 480 & 0 & 8.35 & 38 & \\
\hline VIC & 22.8 & 14 & $<0.3$ & 0 & 580 & 0 & 8.34 & 39 & \\
\hline VID & 22.6 & 14 & $<0.3$ & 0 & 580 & 0 & 8.30 & 39 & \\
\hline VIE & 21.7 & 14 & $<0.3$ & 0 & 580 & 0 & 8.32 & 40 & \\
\hline
\end{tabular}


Tab. 4: Physical/chemical parameters collected during summer.

\begin{tabular}{|c|c|c|c|c|c|c|c|c|c|}
\hline pool & $\begin{array}{c}\text { Temp. } \\
\left({ }^{\circ} \mathrm{C}\right)\end{array}$ & $\begin{array}{c}\mathrm{O}_{2} \\
(\mathrm{mg} / \mathrm{l})\end{array}$ & $\begin{array}{c}\mathrm{NO}_{2} \\
(\mathrm{mg} / \mathrm{l})\end{array}$ & $\begin{array}{c}\mathrm{NO}_{3} \\
(\mathrm{mg} / \mathrm{l})\end{array}$ & $\begin{array}{c}C a^{2} \\
(m g / l)\end{array}$ & $\begin{array}{c}\mathrm{PO}_{4}^{3-} \\
(\mathrm{mg} / \mathrm{l})\end{array}$ & $p H$ & $\begin{array}{c}\text { Salinity } \\
\text { (psu) }\end{array}$ & date and hour \\
\hline$I A$ & no data & no data & no data & no data & no data & no data & no data & no data & \multirow{5}{*}{ 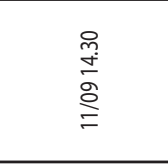 } \\
\hline$I B$ & no data & no data & no data & no data & no data & no data & no data & no data & \\
\hline$I C$ & 29.4 & 14 & $<0.3$ & 8 & no data & 0 & 8.95 & 35 & \\
\hline$I D$ & 26.2 & 11 & $<0.3$ & 0 & no data & 0 & 8.49 & 35 & \\
\hline$I E$ & 27.0 & 11 & $<0.3$ & 0 & no data & 0 & 8.18 & 35 & \\
\hline$I I A$ & 30.5 & 14 & $<0.3$ & 12.5 & no data & 0 & 8.61 & 37 & \multirow{4}{*}{$\begin{array}{l}\text { 엉 } \\
\text { ò } \\
\text { ô }\end{array}$} \\
\hline II B & 29.0 & 11 & $<0.3$ & 12.5 & no data & 0 & 8.67 & 32 & \\
\hline$I I C$ & 27.9 & 14 & $<0.3$ & 0 & no data & 0 & 8.40 & 35 & \\
\hline IID & 26.5 & 14 & $<0.3$ & 0 & no data & 0 & 8.26 & 34 & \\
\hline III A & no data & no data & no data & no data & no data & no data & no data & 94 & \multirow{4}{*}{ 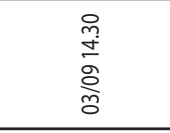 } \\
\hline III B & 27.1 & 14 & $<0.3$ & 0 & 560 & 0 & 8.24 & 31 & \\
\hline IIIC & 26.3 & 14 & $<0.3$ & 0 & 500 & 0 & 8.04 & 35 & \\
\hline$I I I D$ & 26.6 & 14 & $<0.3$ & 0 & 500 & 0 & 8.32 & 35 & \\
\hline$I V A$ & 22.0 & 8 & 0.8 & 12.5 & 160 & 0.5 & 8.00 & 0 & \multirow{6}{*}{ 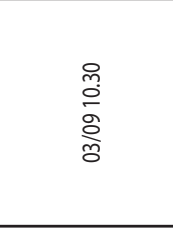 } \\
\hline$I V C$ & 23.5 & 11 & 0.5 & 12.5 & 240 & 0.2 & 7.94 & 17 & \\
\hline$I V D$ & 23.9 & 8 & $<0.3$ & 12 & 380 & 0 & 8.05 & 20 & \\
\hline$I V E$ & 25.0 & 11 & $<0.3$ & 8 & 440 & 0 & 8.09 & 18 & \\
\hline$I V F$ & 25.6 & 14 & $<0.3$ & 0 & 520 & 0 & 8.19 & 36 & \\
\hline$I V G$ & 25.6 & 14 & $<0.3$ & 0 & 520 & 0 & 8.19 & 36 & \\
\hline$V A$ & 29.4 & 11 & 0.3 & 0 & no data & 0 & 8.07 & 33 & \multirow{4}{*}{ 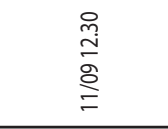 } \\
\hline$V B$ & 27.3 & 14 & $<0.3$ & 0 & no data & 0 & 8.48 & 32 & \\
\hline$V C$ & 26.2 & 14 & $<0.3$ & 0 & no data & 0 & 8.35 & 34 & \\
\hline$V D$ & 26.2 & 14 & $<0.3$ & 0 & no data & 0 & 8.35 & 34 & \\
\hline$V I A$ & 24.7 & 11 & $<0.3$ & 0 & no data & 0 & 8.09 & 35 & \multirow{5}{*}{$\begin{array}{l}8 \\
\text { 음 } \\
\text { 을 } \\
=\end{array}$} \\
\hline$V I B$ & 25.1 & 8 & $<0.3$ & 0 & no data & 0 & 8.16 & 34 & \\
\hline$V I C$ & 25.0 & 11 & $<0.3$ & 0 & no data & 0 & 8.20 & 35 & \\
\hline VID & 25.4 & 11 & $<0.3$ & 0 & no data & 0 & 8.20 & 35 & \\
\hline$V I E$ & 25.4 & 11 & $<0.3$ & 0 & no data & 0 & 8.20 & 35 & \\
\hline
\end{tabular}
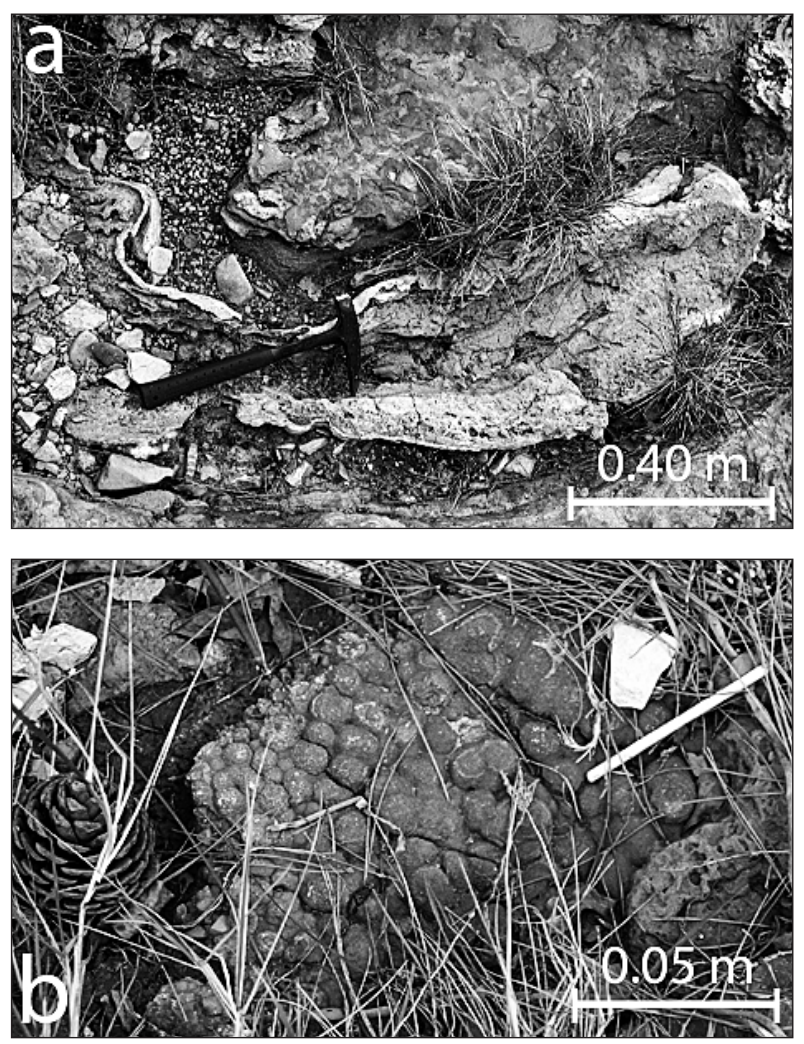

Tab. 5: Mean values of variables in the clusters.

\begin{tabular}{c|c|c|c}
\hline cluster & $\begin{array}{c}\text { Bottom height } \\
(\boldsymbol{m})\end{array}$ & $\begin{array}{c}\text { Elevation } \\
(\boldsymbol{m} \text { m.s.l. })\end{array}$ & $\begin{array}{c}\text { Distance from the } \\
\text { shore } \\
(\boldsymbol{m})\end{array}$ \\
\hline$A$ & -0.20 & 0.20 & 1.86 \\
\hline$M$ & -0.29 & -0.11 & -5.28 \\
\hline$B$ & -0.65 & -0.45 & -12.74 \\
\hline
\end{tabular}

- 3-5 cm laminated grey limestone with sporadic Rudist fragments.

Zambratija transects (Fig. 3): three limestone beds, Cenomanian in age, occur. The bedding strike direction is E $120 \mathrm{~S}$ with respective dip angle of 12 . From the bottom to the top, beds are defined as follows:

- $60 \mathrm{~cm}$ light grey limestone with mudstone-wackestone texture;

- $40 \mathrm{~cm}$ grey very fossiliferous limestone with packstone texture; there are several Rudists, intact or in fragments;

- $60 \mathrm{~cm}$ light grey limestone with mudstone texture.

Fig. 7: $a, b)$ Terra rossa and karst deposits in the pools at higher altitudes at Savudrija (Photos: S. Furlani). 


\section{CHEMICAL/PHYSICAL PARAMETERS}

Collected data are reported in Tab. 2-4, depending on the season. Sometimes, the absence of water prevented the measurements.

During winter (Tab. 2), temperatures ranged between 2.9 and $13.3^{\circ} \mathrm{C}, \mathrm{O}_{2}$ ranged between 8 and $14 \mathrm{mg} / \mathrm{l}$, $\mathrm{NO}_{2}$ was $0.3 \mathrm{mg} / \mathrm{l}$ or smaller, $\mathrm{NO}_{3}$ ranged between 0 and $12.5 \mathrm{mg} / \mathrm{l}, \mathrm{Ca}^{2+}$ ranged between 120 and $900 \mathrm{mg} / \mathrm{l}, \mathrm{PO}_{4}^{3-}$ was always $0, \mathrm{pH}$ ranged between 7.60 and 9.6, while salinity ranged between 0 and 65 psu.

During spring (Tab. 3), temperatures ranged between 19.8 and $28.5^{\circ} \mathrm{C}, \mathrm{O}_{2}$ ranged between 8 and
$14 \mathrm{mg} / \mathrm{l}, \mathrm{NO}_{2}$ was smaller than $0.3 \mathrm{mg} / \mathrm{l}$ up to $0.8 \mathrm{mg} / \mathrm{l}$, $\mathrm{NO}_{3}$ ranged between 0 and $12.5 \mathrm{mg} / \mathrm{l}, \mathrm{Ca}^{2+}$ ranged between 480 and $700 \mathrm{mg} / \mathrm{l}, \mathrm{PO}_{4}^{3-}$ was always $0, \mathrm{pH}$ ranged between 8.07 and 9.07, while salinity ranged between 2 and 40 psu.

During summer (Tab. 4), temperatures ranged between 22.0 and $30.5^{\circ} \mathrm{C}, \mathrm{O}_{2}$ ranged between 8 and $14 \mathrm{mg} / \mathrm{l}, \mathrm{NO}_{2}$ was smaller than $0.3 \mathrm{mg} / \mathrm{l}$ up to $0.5, \mathrm{NO}_{3}$ ranged between 0 and $12.5 \mathrm{mg} / \mathrm{l}, \mathrm{Ca}^{2+}$ ranged between 140 and $560 \mathrm{mg} / \mathrm{l}, \mathrm{PO}_{4}^{3-}$ ranged between 0 and $0.5 \mathrm{mg} / \mathrm{l}$, $\mathrm{pH}$ ranged between 7.93 and 8.95, while salinity ranged between 0 and 94 psu.

\section{DISCUSSION}

The western Istrian area is of interest for the occurrence of shore grykes. Few tidepools have been recognized, probably due to the structural and lithological conditions and the active vertical downdrop. Tectonic rates indicate that the area has been subsiding at least since Roman times; in fact archaeological remains lie below sea level (Antonioli et al. 2004, 2007). The pools along the grykes are usually coalescent, resulting in an elongated and continuous enlarged fracture. The elongated form of the studied coastal features and their joint-controlled origin suggested use of the term shore gryke.

The topographical surveying highlights that the transects collected at Savudrija are shorter than those collected at Zambratija, because the coast is flatter in the latter location and this allows the development of wider coastal platforms. However, the longest transect (IV) is located at Zambratija. Its meandering shape could be due to the coalescence of perpendicular joint sets enlarged by subaerial or marine processes, depending on the altitude. The measurements of the elevation of the seaward threshold of the pools allow determination of the elevation at which the single pool comes in contact with the sea and it is filled by seawater. At Savudrija, the elevation of the high-level pools is higher than at Zambratija, because of the morphological setting of the coast.

The multivariate analysis of topographical parameters suggests the occurrence of 3 clusters, marked by the letters $\mathrm{A}, \mathrm{M}$ and $\mathrm{B}$, which are strongly related to the altitude and the distance from the shore (Tab. 5). Ley (1979), studying the tidepools along the Bristol channel, recognized a twofold division of the foreshore, and he divided the karren above and around mid-tide and the karren located in the lower foreshore. The latter are considered residual forms. The dendrogram (Fig. 4) highlights a strong positive correlation between the clusters; the con- sidered topographical parameters decrease proportionally between cluster A and cluster M or B (Tab. 5). Pools belonging to cluster $\mathrm{A}$ can be roughly identified with the pools of the spray zone (supralittoral), while pools belonging to cluster $\mathrm{M}$ and $\mathrm{B}$ are the grykes located in the intertidal or subtidal zone. Generally, differences in altitude correspond to differences in emersion time, which result in extreme changes in physical conditions over a few vertical meters (Harley 2007). As shown in Tab. 1, the pools at higher altitudes (cluster A) have a smooth surface; at their bottom, sub-rounded or rounded pebbles prevail. Locally, terra rossa have been observed also seaward where, generally, bioerosion increases surface roughness. The cluster $\mathrm{M}$ includes mainly the pools located around mean sea level.

The physical conditions along the grykes vary greatly, but in general the larger and deeper a pool and the lower its position on the shore the more it will correspond to a sublittoral habitat, as suggested by Lewis (1964) in terms of temperature, salinity etc. High-level pools can be significantly different from data reported for the Adriatic sea (Giani et al. 2003). However, often the pools are coalescent, so the topography prevents the differentiation of the single pool. Variances can be measured mainly during low tides, in pools that remain isolated from the sea, even for several days or weeks. During winter, the pools IV B and IV C and during spring the pool III A showed lower temperatures than seawater, mainly because they are far from the shore, without contact with the sea. Higher temperatures have been found in the same pools during summer. Differences can be ascribed mainly to the strong evaporation. Even high salinity values are due to the same process (e.g. 94 psu in the pool IIIA during summer). Lower values, which usually are associated with low values in $\mathrm{Ca}^{2+}$ ( I A and 
I B during winter), suggest a rainfall input. Mid-level and low-level pools, which have a continuous salt water return from the sea, have more stable values similar to seawater. Here in fact prevails bioerosion. Low values of $\mathrm{PO}_{4}^{3-}$ or $\mathrm{NO}^{2-}$ have been recorded while $\mathrm{O}_{2}$ shows values similar to the sea. Transect IV highlight the most significant differences, mainly during spring and summer, probably due to the presence of a waste pipe from the camping at the back. As a consequence, $\mathrm{NO}^{3-}, \mathrm{NO}^{2-}$ and $\mathrm{PO}_{4}^{3-}$ was particularly high, No morphologies related to human activity have been recognized in correspondence with this transect.

The collected data suggest the occurrence of a tidal zonation of the processes that influence the evolution of the shore grykes, but the genesis seems to be strongly related to structural and lithological conditions of the study area. In fact, the studied grykes always occur along geological weaknesses and usually show elongated forms. Even if the biological distribution has not been explored deeply in this work, Torunski (1979) suggested that erosion rates along the Northeastern Adriatic coast increase in the intertidal zone due to bioerosion. Cucchi et al. (2006) and Furlani et al. (2009) instead suggested that the combined action of marine weathering processes leads to an increase in the lowering rates up to about
10 times. The close relations between inland and marine grykes force us to relate their origin to an active vertical tectonic subsidence, recognized by several authors (Fouache et al. 2000; Antonioli et al. 2004, 2007) along the western Istrian coast. Tectonic rates indicate that the area has been subsiding at least since Roman times (-0.77 $\mathrm{mm} / \mathrm{y}$ ), reinforcing marine processes on karstic features. The parameters that control the evolution of the grykes are the same as those that control the formation of coastal karren already studied by Perica et al. (2004): the coast inclination in relation to bedding, the lithological nature of the bedrock and the occurrence of joints and the axis of the folds. Thanks to the tectonic downdrop of the area, grykes are gradually shaped by marine processes, mainly bioerosion and sometimes by mechanical abrasion, where rounded pebbles prevail.

Regarding the processes, corrosion acts on the limestones following the variations in chemical and physical parameters occurring at the pools at different elevations. Consequently, high-level pools are influenced mainly by karstic solution and they are often smoothed. Mid- and low-level pools are instead influenced by marine weathering, mainly biological, which increases the roughness of the limestone surface.

\section{CONCLUSIONS}

Morphological features of the shore grykes along the western Istrian coast are closely related to the local tide. High-level pools are influenced by karstic processes and the surface is usually smooth. At their bottom, terrigenous deposits, mainly terra rossa, occur. Seaward, bioerosion prevails and at the bottom of the grykes, sand and rounded pebbles have been found. However, the chemi$\mathrm{cal} /$ physical parameters suggest that grykes at lower altitudes are affected by seawater factors, while pools located at increasing altitudes are gradually affected by rainfall and freshwater or saltwater remaining from the occurrence of rainfalls and storm events.
Shore grykes genesis is strongly controlled by joints, fractures and the axis of folds; usually they show elongated forms, along the geological weakness. Their origin is due to local tectonics, while their development is related to the active vertical tectonic subsidence of the study area. Pools located at higher altitudes are mainly initiated by solution karst processes. Then, thanks to the tectonic downdrop of the area, grykes are gradually shaped by marine processes.

\section{ACKNOWLEDGEMENTS}

We are grateful to Fabio Chersicla for the field surveying, Dott. Paola Ganis for the cluster analysis and Prof. Franco Stravisi for tide gauge data. 


\section{REFERENCES}

Antonioli, F., Carulli, G.B., Furlani, S., Auriemma, R. \& R. Marocco, 2004: The enigma of submerged marine notches in northern Adriatic Sea.- Quaternaria, 8, 27-36.

Antonioli, F., Anzidei, M., Auriemma, R., Gaddi, D., Furlani, S., Lambeck, K., Orrù, P., Solinas, E., Gaspari, A., Karinja, S., Kovačić V. \& L. Surace, 2007: Sea level change during Holocene from Sardinia and Northeastern Adriatic from archaeological and geomorphological data.- Quaternary Science Reviews, 26, 19-21, 2463-2486.

Auriemma, R. \& S. Karinja (eds.), 2008: Terre di mare. Larcheologia dei paesaggi costieri e le variazioni climatiche. Atti del Convegno Internazionale di Studi, $8^{\text {th }}-10^{\text {th }}$ November 2007, Trieste. pp. 497, Piran.

Carrera, F., Cerasuolo, M., Tomasin, A. \& P. Canestrelli, 1995: La nebbia a Venezia nel quarantennio 19511990. Analisi comparata degli andamenti di visibilità, pressione, temperatura e vento.- Istituto Veneto di Scienze, Lettere ed Arti, Commissione di Studio dei provvedimenti per la conservazione e difesa della laguna e della città di Venezia. Rapporti e Studi: 12, 235-271.

Cavaleri, L., Bergamasco, L., Bertotti, L., Bianco, L., Drago, M., Iovenitti, L., Lavagnini, A., Liberatore, G., Martorelli, S., Mattioli, F., Osborne, A.R., Peduli, L., Ridolfo, R., Sclavo, M., Serio, M., Tescaro, N., Ribaldi, S., Tosi, E. \& D. Viezzoli, 1996: Wind and waves in the northern Adriatic Sea.- Il Nuovo Cimento, 19, 1, 1-36.

Chersicla, D., 2009: Caratterizzazione di pozze di marea del litorale istriano (da Salvore-Punta Faro a Zambrattia): approccio multidisciplinare.- Master's Thesis. University of Trieste, pp. 96.

Cucchi, F., Forti, F. \& S. Furlani, 2006: Erosion/dissolution rates of limestone along the Western Istrian shoreline and the Gulf of Trieste.- Geografia Fisica e Dinamica Quaternaria, 29, 61-69.

Dal Cin, R. \& U. Simeoni, 1994: A model for determining the classification, vulnerability and risk in the Southern coastal zone of the Marche (Italy).- Journal of Coastal Research, 10, 1, 18-29.

D’Ambrosi, C., 1948: Notizie geomorfologiche sull'Istria e sui dintorni di Trieste.- Boll. Soc. Adriat. Sci. Nat., 44, 88-107.

Degobbis, D., 1990: A stoichiometric model of nutrient cycling in the Northern Adriatic Sea and its relations to regeneration processes.- Mar. Chem., 29, 235-253.
Denny, M.W. \& S.D. Gaines, 2007: Encyclopedia of Tidepools and Rocky Shores.- University of California Press, pp. 705, Berkeley.

De Waele, J., Mucedda, M. \& L. Montanaro, 2009: Morphology and origin of coastal karst landforms in Miocene and Quaternary carbonate rocks along the central-western coast of Sardinia (Italy).- Geomorphology, 106, 1-2, 26-34.

Dorigo, L., 1965: La laguna di Grado e le sue foci.- Ufficio Idrografico del Magistrato alle Acque di Venezia. Ricerche e Rilievi Idrografici, pp. 231, Venezia.

Faivre, S., Fouache, E., Ghilardi, M., Antonioli, F., Furlani, S. \& V. Kovačić, 2011: Relative sea-level change in western Istria (Croatia) during the last millennium.- Quaternary International, 232, 1-2, 132-143.

Feldmann, J., 1937: Recherches sur la végétation marine de la Mediterraneé: la Cote des Alberes.- Rev. Algol., 10, 1-139.

Fontolan, G., Pillon, S., Delli Quadri, F. \& A. Bezzi, 2007: Sediment storage at tidal inlets in northern Adriatic lagoons: Ebb-tidal delta morphodynamics, conservation and sand use strategies.- Estuarine Coastal and Shelf Science 75, 261-277.

Forti, F., 1985: Fenomeni di carsismo marino (studi sul Carso Triestino).- Atti e Mem. Comm. Grotte "E. Boegan", 23, 47-60.

Fouache, E., Faivre, S., Dufaure, J.J., Kovačić, V. \& F. Tassaux, 2000: New observation on the evolution of the Croatian shoreline between Poreč and Zadar over the past 2000 years.- Zeitschrift fur Geomorphologie, 122, 33-46.

Furlani, S., Cucchi, F., Forti, F. \& A. Rossi, 2009: Comparison between coastal and inland Karst limestone lowering rates in the northeastern Adriatic Region (Italy and Croatia).- Geomorphology, 104, 73-81.

Furlani, S., Biolchi, S., Cucchi, F., Antonioli, F., Busetti, M. \& R. Melis, 2011a: Tectonic effects on Late-Holocene sea level changes in the Gulf of Trieste (NE Adriatic Sea, Italy).- Quaternary International, 232, 1-2, 144-157.

Furlani, S., Cucchi, F., Biolchi, S. \& R. Odorico, 2011b: Notches in the Northern Adriatic Sea: Genesis and Development.- Quaternary International, 232, 1-2, 158-168.

Gamboni, E., 1965: Sul caposaldo fondamentale di riferimento della nuova rete altimetrica di alta precisione.- Boll. Geodesia Sc. Aff., 1, 155-165.

Giani, M., Savelli, F. \& A. Boldrin, 2003: Temporal variability of particulate organic carbon, nitrogen and phosphorus in the Northern Adriatic Sea.- Hydrobiologia, 494, 319-325. 
Griggs, G., 2007: Tidepools, formation and rock types.In: Denny, M.W. \& S.D. Gaines (eds.) Encyclopedia of Tidepools and Rocky Shores. University of California Press, pp. 586-588, Berkeley.

Harley, C., 2007: Zonation.- In: Denny, M.W. \& S.D. Gaines (eds.) Encyclopedia of Tidepools and Rocky Shores. University of California Press, pp. 647-653, Berkeley.

Hunt, L.J.H., 2007: Surveying.- In: Denny, M.W. \& S.D. Gaines (eds.) Encyclopedia of Tidepools and Rocky Shores. University of California Press, pp. 564-568, Berkeley.

Jarvis, A., Reuter, H.I., Nelson, A., \& E. Guevara, 2008: Hole-filled seamless SRTM data V4.- International Centre for Tropical Agriculture (CIAT). [Online] Available from: http://srtm.csi.cgiar.org [Accessed ?].

Krom, M.D., Kress, N., Brenner, S. \& L.I. Gordon, 1991: Phosporus limitation of primary production in the eastern Mediterranean sea.- Limnol. Oceanogr., 36, 424-432.

Ley, R.G., 1979: The development of marine karren along the Bristol Channel coastline.- Zeitschrift fur Geomorphologie, Suppl.-Bd., 32, 75-89.

Lewis, J.R., 1964: The ecology of rocky shores.- The English University Press, pp. 323, London.

Matičec, D., 1994: Neotectonic deformations in western Istria, Croatia.- Geol. Croat., 47/2, 199-204.

Monroe, W. H., 1970: A Glossary of Karst Terminology.Geological Survey Water-Supply Paper 1899-K. U.S. Geological Survey. U.S. Government Printing Office, pp. 26, Washington, D.C.

Perica, D., Marjanac, T., Aničić, B., Mrak, I. \& M. Juračić, 2004: Small karst features (karren) of Dugi Otok island and Kornati archipelago coastal karst (Croatia).- Acta Carsologica, 33/1, 8, 117-130.

Pleničar, M., Polšak, A. \& D. Šikić, 1973: Osnovna Geološka karta SFRJ. 1:100.000. Tolmač za list Trst (Geology of Trieste sheet).- Zvezni geološki zavod, 68 , Beograd.
Polli, S., 1970: Tabelle di previsione delle maree per Trieste e l'Adriatico Settentrionale per l'anno 1971.- Istituto Talassografico Sperimentale, 20, Trieste.

Stravisi, F., 2003: Caratteristiche meteorologiche e climatiche del Golfo di Trieste.- In: Bussani, M. \& S.A.S. Hydrores (eds.) Manuale del conduttore-motorista alla pesca locale professionale. pp. 148-154, Trieste.

Stravisi, F. \& N. Purga, 2005: Il livello del mare a Trieste: piani di riferimento e statistiche.- Univ. Trieste, Dip. Sc. Terra, Rapp. Oceanogr. Meteor., 112, 10.

Trenhaile, A.S., 1987: The Geomorphology of Rock Coasts.- Claredon Press, pp. 384, Oxford.

Tommasini, T., 1979: Dieci anni di osservazioni meteorologiche a Borgo Grotta Gigante sul Carso Triestino (1967-1976).- Atti e Mem. Comm. Grotte "E. Boegan", 1-11.

Torunski, H., 1979: Biological erosion and its significance for the morphogenesis of limestone coasts and for nearshore sedimentation (northern Adriatic).Senckenbergiana maritima, 11, 3(6), 193-265.

Velić, I., Vlahović, J. \& D. Matičec, 2002: Depositional sequences and Palaeogeography of the Adriatic Carbonate Platform.- Mem. Soc. Geol. It., 57, 141-151.

Vlahović, I., Tišljar, J., Velić, I. \& D. Matičec, 2005: Evolution of the Adriatic Carbonate Platform: Paleogeography, main events and depositional dynamics.- $\mathrm{Pa}$ laeogeography, Palaeoclimatology, Palaeoecology, 220, 333-360.

Zavatarelli, M., Raicich, F., Bregant, D., Russo, A. \& A. Artegiani, 1998: Climatological biogeochemical characteristics of the Adriatic Sea.- J. Mar. Sys., 18, 227-263. 